\title{
Modified transport and growth medium for the cultivation of Neisseria gonorrhoeae
}

\author{
J. D. BROWN \\ Bacteriology Department, The General Hospital, Birmingham B4 6NH
}

Transgrow medium was developed by Martin and Lester (1971) as a combined transport and culture medium for $N$. gonorrhoeae and $N$. meningitidis. It has since become widely used in the United States, where it is considered to be an important aid in the diagnosis of gonorrhoea in patients attending clinics which are remote from a laboratory. Certain of the ingredients of Transgrow are difficult to obtain in the United Kingdom and are expensive. The object of this study was to produce and evaluate a modified Transgrow medium using easily available ingredients, achieving the criteria of acceptability laid down by the U.S. Department of Health.

\section{Material and methods}

The medium used differed from that described by Martin and Lester (1971) in that Columbia agar was used instead of GC medium base (Difco or BBL) and fresh horse blood instead of dried haemoglobin with a defined supplement.

$39 \mathrm{~g}$. Columbia agar (Oxoid) were suspended in 1 litre distilled water, autoclaved at $121^{\circ} \mathrm{C}$. for $15 \mathrm{~min}$., and cooled to $50^{\circ} \mathrm{C} .100 \mathrm{ml}$. horse blood were added, and the mixture heated to $80^{\circ} \mathrm{C}$. After cooling to $50^{\circ} \mathrm{C}$., $10 \mathrm{ml}$. antibiotic mixture (VCT) containing vancomycin 300 units $/ \mathrm{ml}$., colistin $750 \mu \mathrm{g} . / \mathrm{ml}$., and trimethoprim 300 $\mu \mathrm{g} . / \mathrm{ml}$., and $10 \mathrm{ml}$. 25 per cent. glucose solution were added.

The medium was distributed aseptically into sterile $1 \mathrm{oz}$. tablet bottles fitted with metal caps and rubber liners (Beatson) in $9 \mathrm{ml}$. amounts, using an Accuramatic dispenser (Jencons Ltd.), and allowed to solidify in the sloping position.

The bottles were then placed in a glass dessicator in the upright position with the caps loosened, and the air was partially extracted with a vacuum pump and replaced with 10 per cent. $\mathrm{CO}_{2}$ in air (British Oxygen, Special Gases Division) through a microfibre glass prefilter (Millipore). The procedure was then repeated twice. The bottle caps were tightened and the bottles stored in the upright position at $4^{\circ} \mathrm{C}$. for one week.

After being allowed to reach ambient temperature, the bottles were examined for homogeneity of the medium and excess fluid content, which should not exceed $0.2 \mathrm{ml}$.

Received for publication October 3, 1973
The $\mathrm{CO}_{2}$ qualitative test recommended by the U.S Department of Health, Venereal Diseases Research Laboratory (1971), was applied:

Equal parts of $0.1 \mathrm{~N} \mathrm{Na}_{2} \mathrm{CO}_{3}$ and 0.1 per cent. phenolphthalein in 50 per cent. ethyl alcohol were freshly mixed. The bottle being tested was held upright and the cap removed, and $1 \mathrm{ml}$. of the indicator mixture was introduced, without blowing, into the bottle. The cap was replaced and the bottle shaken vigorously. A change of indicator colour from violet to colourless in $1 \mathrm{~min}$. or less indicated 5 per cent. or more gaseous $\mathrm{CO}_{2}$. Ungassed bottles were used as controls. Three or more bottles from each batch were tested.

The medium was tested for its ability to support growth with a known stock culture of $\mathrm{CO}_{2}$-dependent $N$. gonorrhoeae or three fresh isolates, and the growth was compared with that on standard media. Tests for sterility were made by incubating three or more bottles of each batch at $37^{\circ} \mathrm{C}$. for 3 days.

Duplicate cultures were made, using Transgrow and conventional Thayer-Martin medium (Thayer and Martin, 1966), of material from the urethra in men and the cervix in women at their first attendance at the clinic. In the case of specimens from men the Transgrow was inoculated first but there was no particular order for the specimens from women. The conventional plates were inoculated directly in the clinic and incubated straight away. The Transgrow was inoculated by holding the bottle upright to minimize loss of $\mathrm{CO}_{2}$, removing the cap and rolling the swab across the surface of the agar. The cap was then replaced and tightened.

The trial was conducted in two phases:

(1) The cultures were inoculated and the bottles incubated for 12 to $18 \mathrm{hrs}$ at $37^{\circ} \mathrm{C}$. in the clinic; some were then posted to the laboratory and others sent by alternative means. All were in transit and at ambient temperatures for a minimum of $48 \mathrm{hrs}$, the longest taking $96 \mathrm{hrs}$. On receipt at the laboratory they were examined for oxidasepositive colonies which were taken for Gram-staining and identification. All negative cultures were incubated for a further $24 \mathrm{hrs}$ and re-examined. The Thayer-Martin cultures were reported by the laboratories normally handling this work. The results of these cultures were not available until the Transgrow results were recorded.

(2) Cultures were made in the same way, but the initial incubation of the Transgrow medium at the clinic was 
omitted. Transit times were similar, cultures being 48 to $96 \mathrm{hrs}$ at ambient temperatures before being incubated at $37^{\circ} \mathrm{C}$. They were examined at 24 and $48 \mathrm{hrs}$, and the results were compared with those obtained with the Thayer-Martin medium as before.

The clinics taking part in the trial were the Wolverhampton Special Clinic, the Coventry Special Clinic, and the City of Birmingham girls remand home.

\section{Results}

The results of the first phase of the trial are given in Table I. All cultures with visible colonies on arrival at the laboratory proved to be viable on sub-culture. The numbers of cultures with growth other than Neisseria was comparable with that on ThayerMartin medium; no cultures were heavily overgrown and no Proteus $s p$. were encountered. The results of the second phase of the trial are given in Table II. The numbers of positive cultures on Transgrow medium in both phases of the trial were comparable with those on Thayer-Martin medium.

\section{Discussion}

The modification described is easily prepared from familiar ingredients. The cost is little more than for a conventional agar plate and less than a semi-solid transport medium plus a Thayer-Martin agar plate. The slightly better recovery rate on the Transgrow than on the Thayer-Martin cultures was probably due to the absence of trimethoprim in plates prepared in one laboratory, where cultures reported as positive on Transgrow were overgrown with Proteus on Thayer-Martin medium. The apparent decrease in the percentage of positive cultures in females in
Table II can be explained by a high number of cultures from the remand home where the incidence of gonorrhoea was much lower than in females attending clinics.

The results of this trial show that the efficiency of the Transgrow modification was comparable with conventional Thayer-Martin plate cultures for the isolation of $N$. gonorrhoeae. There was little difference in the recovery rates when there had been 12 to 18 hrs' incubation before transportation, and when incubation had been delayed for 48 to $96 \mathrm{hrs}$. Transgrow is an easily prepared and convenient method for transporting cultures of $N$. gonorrhoeae. It does not require the use of a candle extinction jar or incubator in the clinic or doctor's surgery where on-site laboratory facilities are not available. Its use may also be considered in family planning and pregnancy advisory clinics where large numbers of females at risk are seen. Satisfactory results have been obtained after storage of the medium for 3 months at $4^{\circ} \mathrm{C}$., but the full shelf life has not been assessed.

\section{Summary}

A transport and growth medium for the cultivation of $N$. gonorrhoeae is described. It consists of a modification of Transgrow medium which is relatively cheap and easy to prepare. The recovery rates of $N$. gonorrhoeae from the male urethra and female cervix using this medium were comparable with those using conventional Thayer-Martin medium.

The author wishes to acknowledge the technical assistance of Mrs. J. Tomkyns, and to express his appreciation to Dr. Rahim and staff at Wolverhampton, Dr. O'Keefe and Dr. Guilbride and staff at Coventry, Dr. Hansell and the

TABLE I Comparison of cultures for N. gonorrhoeae on modified Transgrow and Thayer-Martin medium after preliminary incubation

\begin{tabular}{|c|c|c|c|c|c|c|}
\hline \multirow[t]{2}{*}{ Site } & \multirow{2}{*}{$\begin{array}{l}\text { Total no. of } \\
\text { cultures }\end{array}$} & \multicolumn{2}{|c|}{ Transgrow positive } & \multicolumn{2}{|c|}{ Thayer-Martin positive } & \multirow{2}{*}{$\begin{array}{l}\text { No. positive on } \\
\text { Transgrow after } \\
12 \text { to } 18 \text { hrs }\end{array}$} \\
\hline & & No. & Per cent. & No. & Per cent. & \\
\hline $\begin{array}{l}\text { Male urethra } \\
\text { Female cervix }\end{array}$ & $\begin{array}{r}77 \\
157\end{array}$ & $\begin{array}{l}39 \\
42\end{array}$ & $\begin{array}{l}50 \cdot 6 \\
26 \cdot 7\end{array}$ & $\begin{array}{l}36 \\
37\end{array}$ & $\begin{array}{l}46 \cdot 7 \\
23 \cdot 6\end{array}$ & $\begin{array}{l}16 \\
12\end{array}$ \\
\hline
\end{tabular}

TABLE II Comparison of cultures for $\mathrm{N}$. gonorrhoeae on modified Transgrow and Thayer-Martin medium without preliminary incubation

\begin{tabular}{|c|c|c|c|c|c|c|}
\hline \multirow[t]{2}{*}{ Site } & \multirow{2}{*}{$\begin{array}{l}\text { Total no. of } \\
\text { cultures }\end{array}$} & \multicolumn{2}{|c|}{ Transgrow positive } & \multicolumn{2}{|c|}{ Thayer-Martin positive } & \multirow{2}{*}{$\begin{array}{l}\text { No. positive on } \\
\text { Transgrow after } \\
12 \text { to } 18 \text { hrs }\end{array}$} \\
\hline & & No. & Per cent. & No. & Per cent. & \\
\hline $\begin{array}{l}\text { Male urethra } \\
\text { Female cervix }\end{array}$ & $\begin{array}{r}70 \\
100\end{array}$ & $\begin{array}{l}35 \\
17\end{array}$ & $\begin{array}{l}50 \cdot 0 \\
17 \cdot 0\end{array}$ & $\begin{array}{l}32 \\
14\end{array}$ & $\begin{array}{l}45 \cdot 7 \\
14 \cdot 0\end{array}$ & $\begin{array}{r}18 \\
5\end{array}$ \\
\hline
\end{tabular}


staff of the remand home at Clent, and finally to Mrs. A. Redfern for secretarial assistance.

\section{References}

Martin, J. E. JR., and Lester, A. P. (1971) HSMHA Hlth Rep., 86, 30

Thayer, J. D., and Martin, J. E., JR. (1966) Publ. Hlth Rep. (Wash.), 81, 559

U.S. Department of Health, Education and Welfare (1971 'Protocol for Testing of Transgrow by Producers'. Venereal Disease Research Laboratory, Atlanta, Georgia, U.S.A.
Milieu de transport et de croissance modifié pour la culture de $\boldsymbol{N}$. gonorrhoeae

SOMMAIRE

On décrit un milieu de transport et de croissance pour la culture de $N$. gonorrhoeae. Ce milieu consiste en une modification du milieu Transgrow qui le rend relativement bon marché et facile à préparer. Le taux de mise en évidence de $N$.gonorrhoeae dans l'urètre masculin ou le col utérin fut comparable pour ce milieu à ce que l'on obtient par le milieu de Thayer-Martin conventionnel. 